\title{
OBSERVATIONS ON CHYTRIDIACEOUS PARASITES OF PHANEROGAMS. XIX. A PHYSODERMA ON EURASIAN WATER MILFOIL (MYRIOPYLLUM SPICATUM) ${ }^{1}$
}

\author{
Frederick K. Sparrow \\ Botany Department, University of Michigan, Ann Arbor
}

A B S T R A C T

\begin{abstract}
A Physoderma was found on Myriophyllum spicatum in Michigan. This is the first recorded on this host from this hemisphere. It differs from the Danish P. myriophylli Rostrup in not producing galls on the host and in several aspects of its endobiotic stage. It more closely resembles a Swedish fungus attributed to Physoderma hippuridis by Lagerheim occurring on the same species of host.
\end{abstract}

Myriophyllum SPICATUM L. is a waterweed of Eurasian origin which has been steadily increasing in abundance in our northern lakes and ponds and in some instances to the detriment of our common native species (primarily $M$. exalbescens and $M$. heterophyllum). Apparently it has brought along with it a chytridiaceous parasite, possibly an unrecorded species of Physoderma. In fact, no Physoderma has been heretofore recorded on Myriophyllum from this hemisphere. It will be recalled that in this fungus genus (and family, Physodermataceae) there are two distinct and independent phases in the life history. The endobiotic, which is composed of a polycentric rhizoidal vegetative system bearing occasional swellings and nucleated, usually septate "turbinate cells," forms on it numerous disproportionately large, dark-colored resting spores which are aggregated in areas in the host tissue. It is these aggregations which cause external manifestations on the host such as dark flecks, pustules, etc. There is also formed from zoospores produced at germination of resting spores a second type of thallus which is epibiotic monocentric and bears within the host epidermal cell a short bushy rhizoidal system. The epibiotic zoospore rudiment enlarges and ultimately becomes converted into a zoosporangium much as does a chytrid such as Rhizophydium. The zoospores from this phase in most of

${ }^{1}$ Received for publication 23 April 1973.

Acknowledgment is made to the National Science Foundation for support of this research (Grant GB 3333). the species studied by me, including the type of the genus, $P$. maculare, can give rise either to a new epibiotic phase or, without fusions, to an endobiotic one (Sparrow, 1964). Occasionally, as in the Physoderma on swamp milkweed (Asclepias incarnata) (Sparrow and Johns, 1970) fusions of these zoospores have been seen, but the fate of the fused elements could not be followed. In yet another species, $P$. claytonianum, no epibiotic stage has as yet been found (Sparrow and Griffin, 1961).

OCCURRENCE-The present material was obtained in some abundance on both vegetative and flowering material of Myriophyllum spicatum L. in Square Lake, Oakland County, Michigan, 17 October 1972. It appears on the internodes of the main stems, often near the base, as reddishbrown to nearly black flecks of varying shape and size (Fig. 3). There is no swelling or distortion of the stem or gall formation where infection occurs nor are there pustules. No infection of peduncle or leaf rachis was found. Unfortunately, not all such brownish flecks are due to Physoderma infection and only microscopic examination of samples will discover the fungus. It did seem that infected parts of stems browned-off and died before uninfected ones.

Only subepidermal cells harbor the polycentric thallus which bears the resting spores and these are not noticeably altered in any way from uninfected ones and there are no lysed areas. A

Fig. 1-5. Physoderma infections of Myriophyllum. 1. Gall produced by $P$. myriophylli Rostrup infection of leafy apex of lateral branch of $M$. verticellatum. From type material. $\times 4$. 2. Portion of stem of $M y r i o p h y l l u m$ spicatum from Sweden, showing dark flecks of a Physoderma infection. Sydow, Exsicc. "Phycomyceten et Protomyceten" No. 178. $\times$ 4. 3. Portion of living stem of $M$. spicatum from Square Lake, Michigan, showing dark flecks of Physoderma infection. $\times 5$. 4. Base of turbinate cell of Michigan Physoderma, showing radiating, unbranched rigid projections; right hand one terminating in a drop-like expansion. $\times 800$. 5 . Two resting spores and attendant turbinate cells; left-hand turbinate cell, showing basal outgrowths and narrow apical region. $\times 800$. 

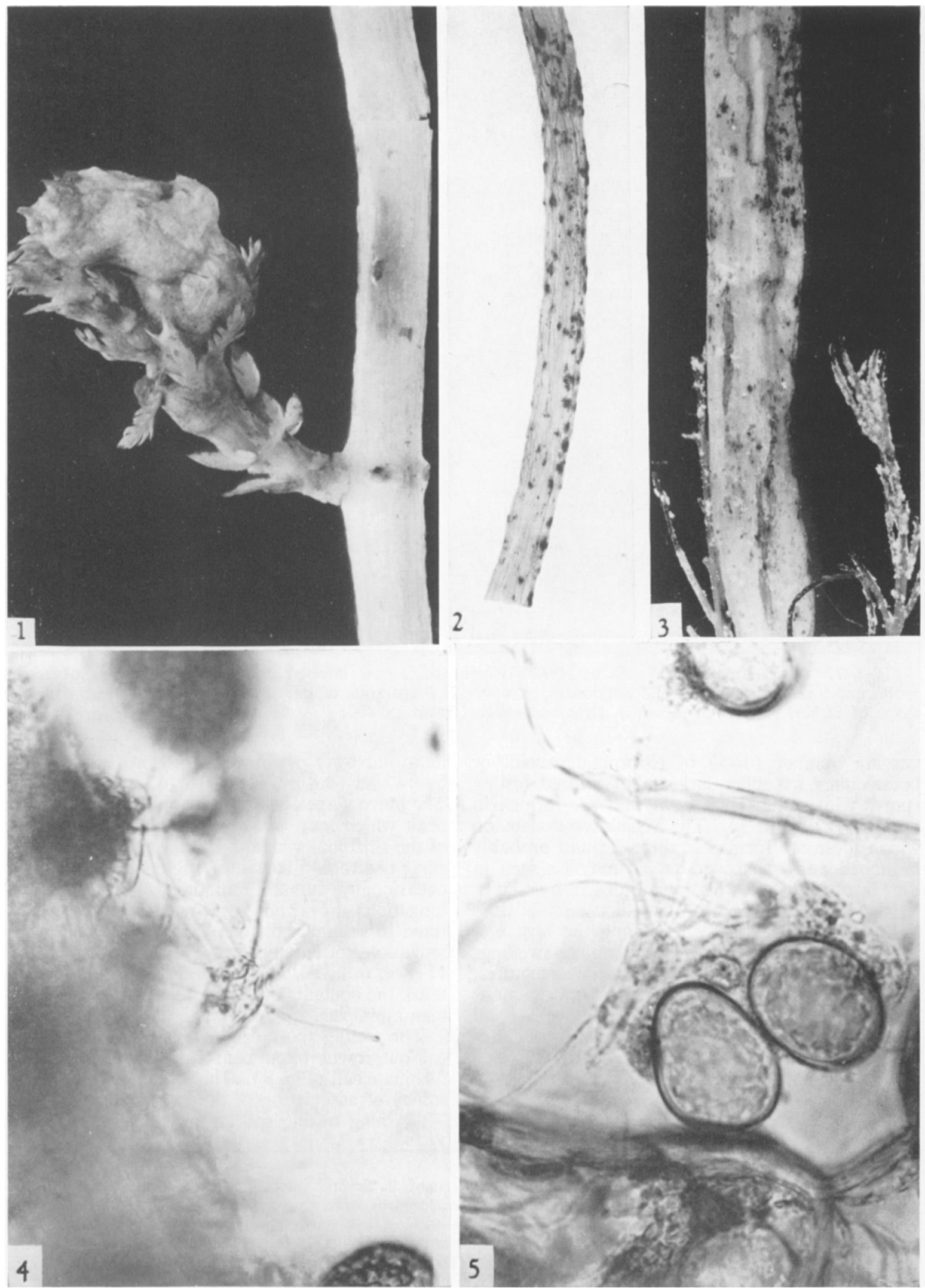

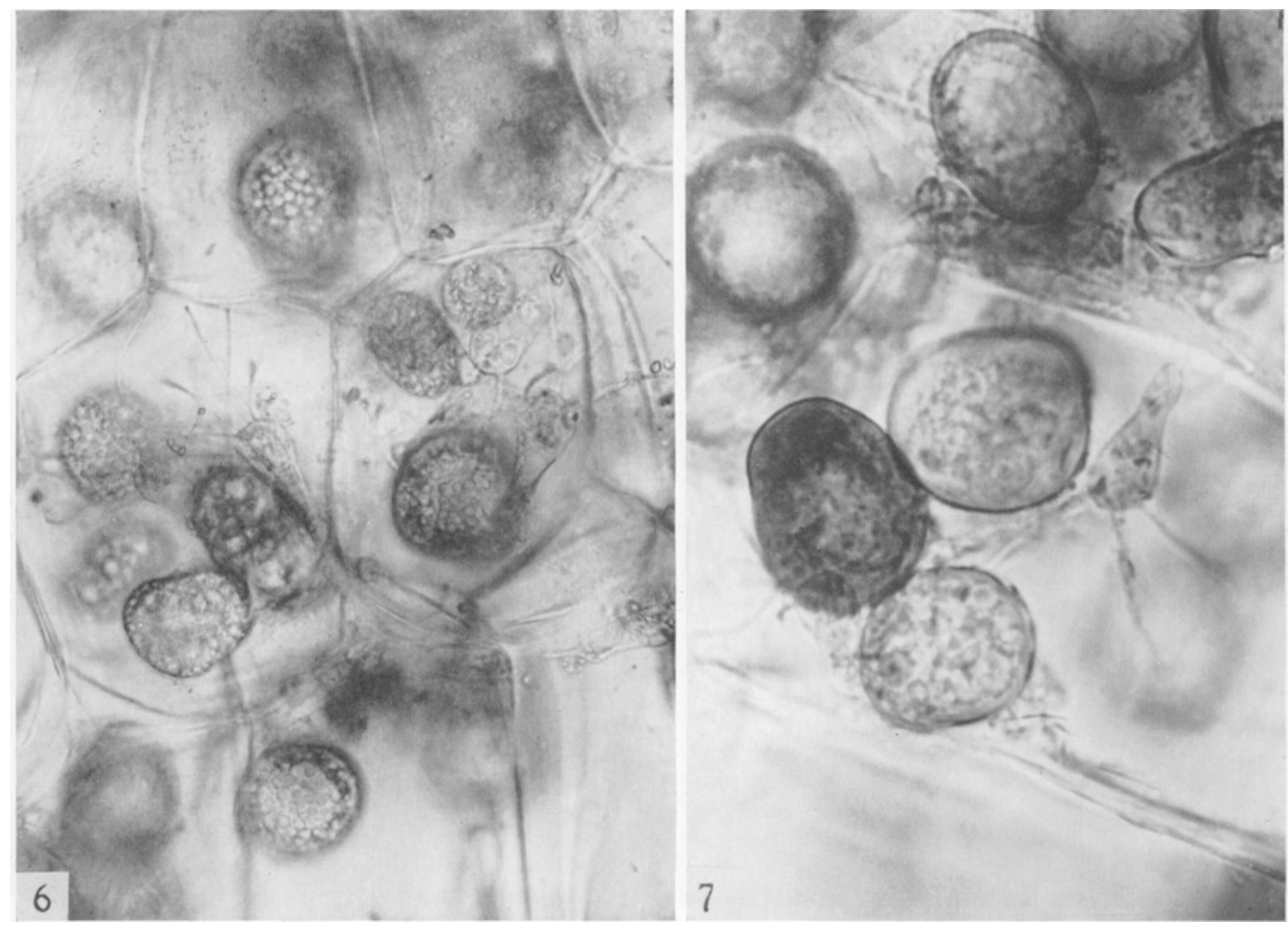

Fig. 6-7. Physoderma-infected cells of Myriophyllum. 6. Several infected cells, showing complex of resting spores and turbinate cell with rigid outgrowths. $\times 450.7$. Preparation of infected cells stained with acid fuchsin; shape of turbinate cell well shown in right hand lower figure. $\times 800$.

varying number (1-5) of ellipsoidal, ovoid, or occasionally irregular dark amber-colored resting spores with a thickened $2 \mu \mathrm{m}$ wall are formed in each cell (Fig. 6, 7). The vegetative system on which these are formed is rhizoidal and probably branched and extensive, but as may be seen in Fig. 6, owing to crowded conditions in host cells, it is difficult to trace for any distance. It does "wander from cell to cell" among the host elements. There are occasional catenulate swellings. and terminal ones bearing haustorial structures, as seen in Fig. 9, but the two most conspicuous elements are the so-called "turbinate cells" and resting spores, always associated with one another.

The turbinate cells (Fig. 7-11) are terminal or more often intercalary and are highly distinctive and unique in several respects. They are unicel- lular, narrowly pyriform, $30-40 \mu \mathrm{m}$ (38 av.) long by $4-7 \mu \mathrm{m}$ ( 4.8 av.) to $8-16$ (13 av.) $\mu \mathrm{m}$ broad. The narrow apex is often tapered into a prolonged beak which may (always?) become an extension of the rhizoidal system. The basal, expanded part gives rise to 1-5 seemingly rigid, usually straight, occasionally curved, radiating, unbranched prolongations $14-42 \mu \mathrm{m}$ in length, which are confined to a single host cell. These bristle-like prolongations often appear to terminate in a knob (Fig. 4, 6, 8, 10, 11). Vacuoles and granulations mark the contents of the turbinate cell but no segmentation occurs.

The resting spore originates as a lateral spherical outgrowth often near the mid-region of the turbinate cell (Fig. 8). This accounts for the constancy of association of the two in the host cells. The young resting spore, particularly at the time

Fig. 8, 9. Myriophyllum cells parastized by Physoderma. 8. Several infected Myriophyllum cells with contents omitted to show resting spores in various stages of development from tip of a projection from turbinate cell; beaked narrowly pyriform turbinate cell shape well shown. 9. Host cells shown nearly without contents. Right hand cell has portion of thallus bearing catenulate enlargements and terminating in left cell in branches bearing young turbinate cell, upper one of which has haustorial cluster. Two resting spores and turbinate cell also shown in right cell. Both $\times 825$. 

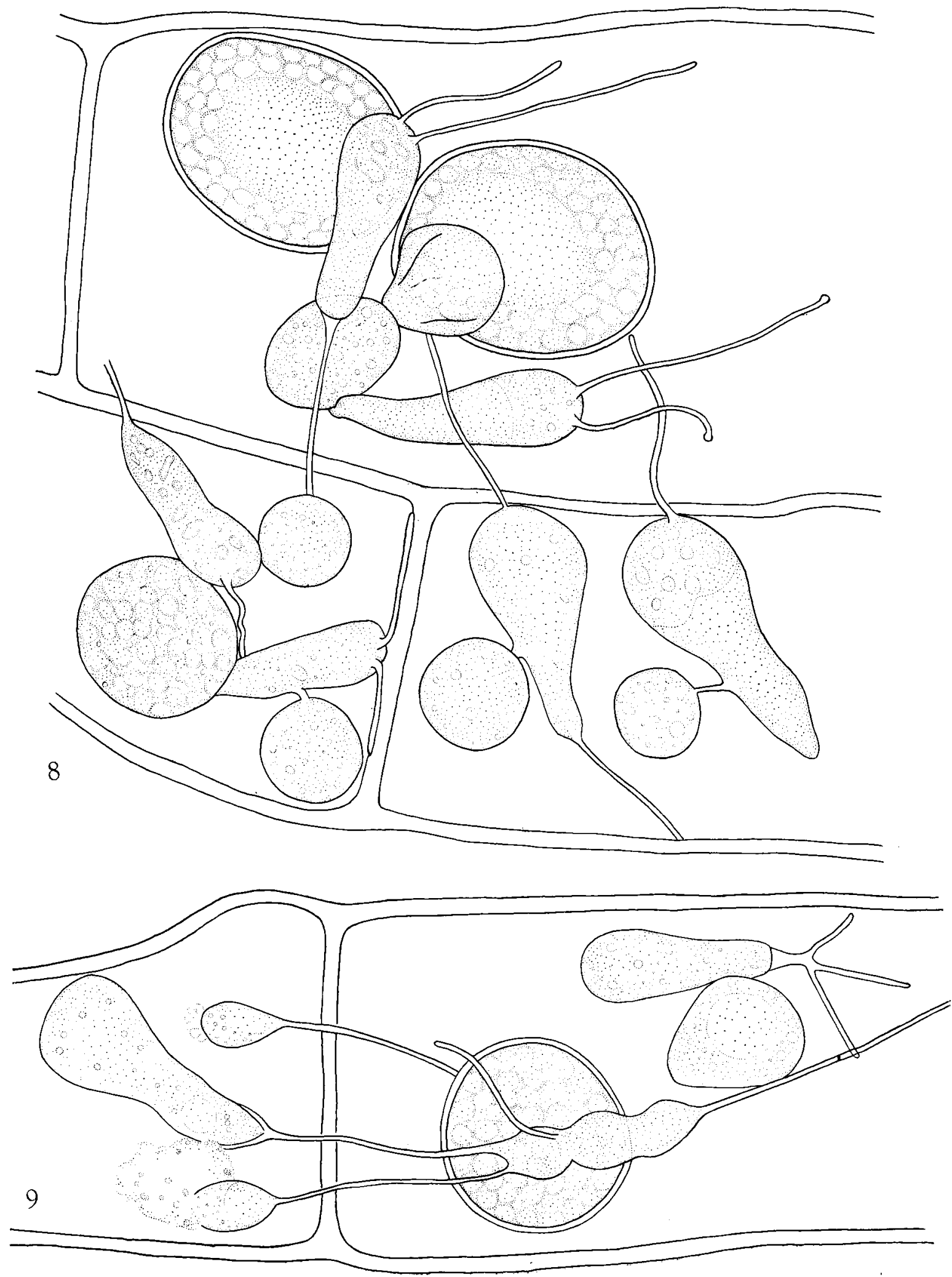
178

AMERICAN JOURNAL OF BOTANY

[Vol. 61
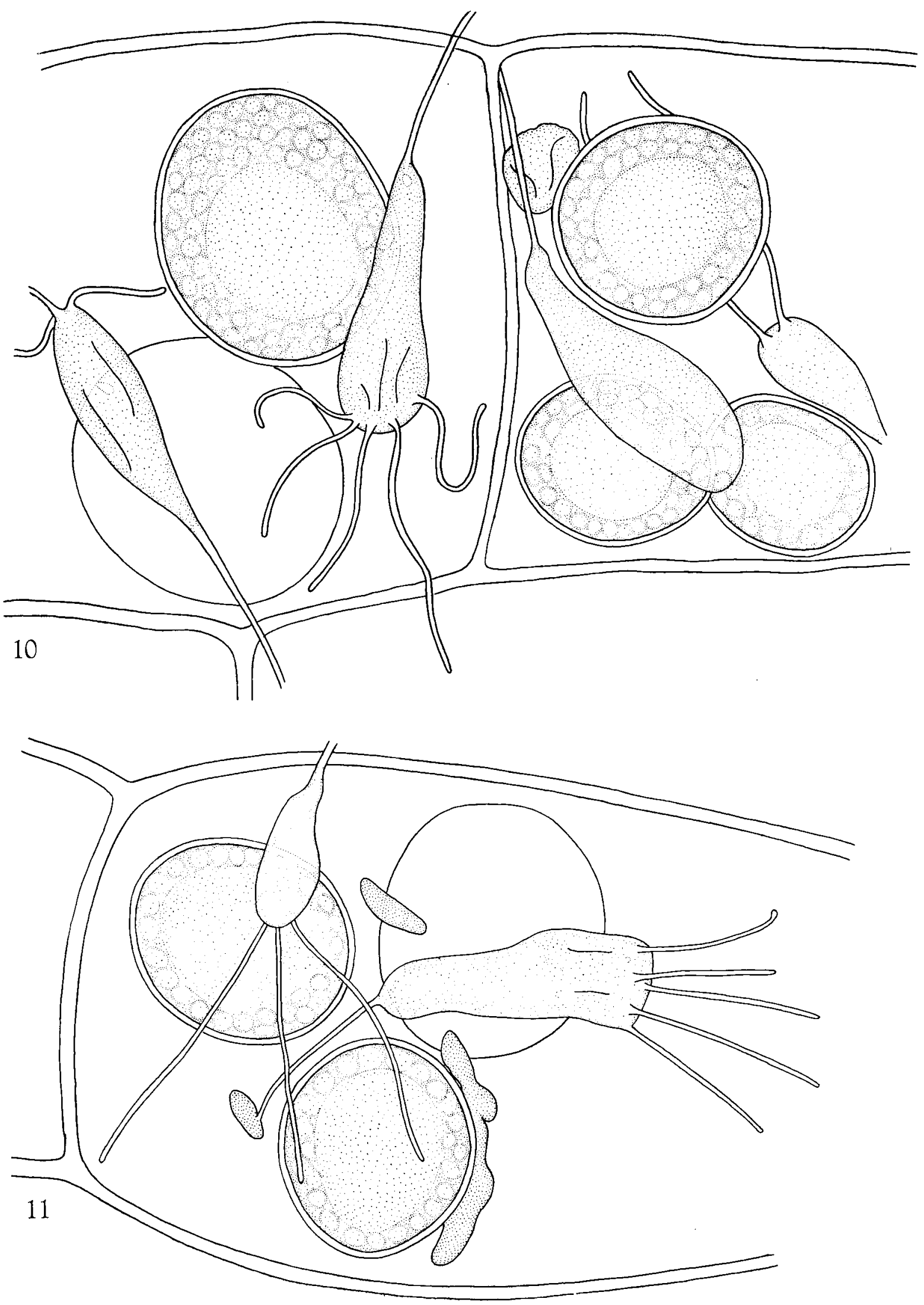
it has achieved full size and thickening and coloration of the wall is initiated, possesses great numbers of highly refractive globules which appear of a fatty nature. At full maturity, the resting spore wall has assumed its mature dark amber coloration and thickness $(2 \mu \mathrm{m})$ and there is present a large central vacuole or "globule," and surrounding this a great number of smaller globules. Resting spores (Fig. $5,6,10,11$ ) which are $25-55 \mu \mathrm{m}$ (av. $35.9 \mu \mathrm{m}$ ) $\times 21-37 \mu \mathrm{m}$ (av. $26.7 \mu \mathrm{m}$ ) show only occasionally the flattened surface so characteristic of many species of the genus. Their germination and the behavior and development of their zoospores will be followed in a subsequent paper.

RELATIONSHIPS - Our fungus invities comparison with several physodermas reported many years ago on Myriophyllum, all known only from the endobiotic stage and only from Scandinavia. The first of these is Physoderma myriophylli (Rostrup) Vestergren, originally described from Denmark (Rostrup, 1905) as Cladochytrium myriophylli Rostrup. From records in Lind (1913) and from material in the Copenhagen Herbarium this fungus was collected from various localities in Denmark, mostly Sealand, by Öve Rostrup, Warming, Harz (in Ferdinandsen and Winge, 1909), O. Hagerup, etc. The outstanding feature of the fungus was its production of galls up to 1 $\mathrm{cm}$ in diam on short lateral host branches. The type material, taken here to be the full herbarium sheet annotated by E. Rostrup, collected by Öve Rostrup at Olstykka Mose, 29.IX.04, well demonstrates this character. Figure 1 shows a young side branch with gall formation involving the apical unfolded whorls of leaves. There were no Physoderma-caused flecks on the main stem. Just as described by Ferdinandsen and Winge (1909), a section of the gall showed the great mass of resting spores to occupy a central position surrounded by starch-filled parenchyma cells and epidermis. Resting spores were $27-43 \mu$ (av. 33.2 $\mu \mathrm{m}) \times 20-33 \mu \mathrm{m}$ (av. $25.0 \mu \mathrm{m}$ ). There was no lysigenous cavity in which the spores nested as in a species of Urophlyctis, nor was any described by Ferdinandsen and Winge. In living material, so far as could be detected, spores rested in proliferated host cells. A herbarium sheet from "Plantae danicae" annotated by H. Luther, shows abnormally expanded fruits of Myriophyllum verticellatum containing Physoderma spores. No instances of flecks, blotches, or pustules on the stem of type material were found, although it must be said, in the interest of the preservation of the type, the search was not too thorough!
Both Rostrup (1905) and Ferdinandsen and Winge (1909) depict the turbinate cells as somewhat broadly pyriform to irregularly saccate structure with 2-5 short unbranched outgrowths which the latter authors considered "emancipated from the mycelium." These turbinate cells were not at all the shape of those of the Michigan fungus. The bits of adherent rhizoids did, however, bear some similarity to the latter's tripod-like pro- longations.

Material collected by Öve Rostrup of his father's species was distributed in Vestergren's "Micromycetes rariores selecti" Fasc. 37 No. 906, issued February 1905 (see Vestergren, 1909), where the correct generic name is used. Parenthetically, this material was collected at the same locality and on the same day as the type.

The second fungus of interest here is Sydow, "Phycomycetes et Protomycetes" No. 178 distributed as Physoderma hippuridis Rostr. on stems of Myriophyllum spicatum from near Stockholm, collected by G. Lagerheim, September, 1900. Lagerheim's material has several points of similarity with our fungus in addition to being on the same species of host. Like Physoderma hippuridis there is no hypertrophy of infected parts (which fact may account for Lagerheim's specific disposition of his fungus), only numerous scattered brown, sessile, or slightly raised flecks up to $1.0 \mathrm{~mm}$ long $\times 0.33 \mathrm{~mm}$ wide on the stem. Resuscitated material shows turbinate cells collapsed to be sure, but elongate, beaked, and bearing (in contrast to $P$. myriophylli) bushy rigid prolongations radiating from one end. Resting spores were 34-42 $\mu \mathrm{m}$ (av. $37.2 \mu \mathrm{m}$ ) $\times 25-37 \mu \mathrm{m}$ (av. 32.2 $\mu \mathrm{m})$, i.e., slightly larger than those of the Michigan material $(35.9 \mu \mathrm{m} \times 27.67 \mu \mathrm{m})$ and of $P$. myriophylli. Otherwise, there is good agreement in external symptoms, lack of hypertrophy, and especially in the nature of the turbinate cell and its appendages. That the Michigan fungus is $P$. hippuridis or a new species distinct from it and from $P$. myriophylli needs data derived from crossinoculation experiments. We believe however, that Lagerheim's and our own material relate to the same species.

For the moment we prefer merely to bring this organism to the attention of future students of the group. As indicated, germination of the resting spores and possible epibiotic stage will be covered in a future paper.

\section{LITERATURE CITED}

Ferdinandsen, C., and Ö. Winge. 1909. Mycological notes. II.A. Danish Fungi. Bot. Tidsskr. 29: 305319.

$\leftarrow$

Fig. 10, 11. Myriophyllum cells infected with Physoderma. 10. Cells free of host contents showing turbinate cells and mature resting spores. 11. Same with some host cell contents. Both $\times 825$. 
LIND, J. 1913. Danish fungi as represented in the herbarium of E. Rostrup. Nordisk Forlag Gyldendalske Boghandel. Copenhagen.

RostruP, E. 1905. Mykologiske meddelelser (IX). Bot. Tidsskr. 26: 305-315.

SparRow, F. K. 1964. Observations on chytridaceous parasites of Phanerogams. xiii. Physoderma maculare Wallroth. Arch. Mikrobiol. 48: 136-149. , AND J. E. GRIFFIN. 1961. Observations on chytridiaceous parasites of Phanerogams. xii. Fur- ther studies of Physoderma claytonianum var. sparrowii. Arch. Mikrobiol. 40: 275-282.

, AND R. M. JoHNs. 1970. Observations on chytridiaceous parasites of Phanerogams. xvii. Notes on a Physoderma parasitic on Asclopias incarnata. Arch. Mikrobiol. 70: 72-81.

Vestergren, T. 1909. Verzeichnis nebst Diagnosen und Bemerkungen zu meinen Exsiccatwerke "Micromycetes Rariores Selecti Fasc. 18-46. Sven. Bot. Tidskr. 3(2): (37-58). 